\title{
SVETA ROŽALIJA U KAZALIŠTU ILI EVO SLIKE SVITA TKO GA VIDIT HOĆE
}

\begin{abstract}
Sažetak
Kazališna praizvedba Svete Rožalije bila je 1999. u Gradskom kazalištu Požega prigodom obilježavanja 300. obljetnice rođenja pisca. Mladi, ali talentirani profesionalni suradnici (redatelj Jasmin Novljaković, adaptacija i dramatizacija Anita Jelić, izbor glazbe i koreografija Jasminka Petek Krapljan, scenografija Miljenko Sekulić, akcentuacija Snježana Mostarkić), uz sudjelovanje petnaest požeških glumaca, članova Srednjoškolske kazališne družine i starijih glumaca postavili su iznimno uspješnu predstavu spajajući barokni tekst, jezik i akcent 18. stoljeća sa suvremenim vizualnim pristupom. Krenuvši od pitanja što nam teme o kojima govori ep poručuju danas, dokazali su da je barokni ep zanimljiv suvremenom gledatelju jer govori o onome što nedostaje suvremenoj sceni smislu života, a kroz likove pokazuje moguće dobre i zle odgovore na životne probleme. Nažalost, to je bila jedina kazališna izvedba (uz jednu radiodramu), ali su Kanižlića kao lik na scenu doveli učenici OŠ Antuna Kanižlića 2017. u predstavi Vrijeme Antuna Kanižlića.
\end{abstract}

Ključne riječi: Antun Kanižlić; hrvatsko kazalište; hrvatska drama, Gradsko kazalište Požega; Anita Jelić; Jasmin Novljaković.

$* * * * * * * * * * * *$

Kao prilično duga epska poema u stihovima bez klasičnog dramskog sukoba, $\mathrm{s}$ brojnim likovima, od kojih su mnogi alegorijski, dugim opisima i raspravama, a s malo radnje, te s neuobičajenim mjestima događanja (poput pakla, raja i čistilišta), Kanižlićeva Sveta Rožalija nije ni pisana za scenu, pa ne čudi da u svoje vrijeme na scenu nije postavljana. Za vrijeme vladavine kršćanskog svjetonazora u kazalištima su se ponajviše igrala prikazanja koja su napisana kao dramska djela, a nakon pobjede sekularnog svjetonazora (1945.) i sama je tema bila odiozna. U razdoblju 1945. - 1990. u hrvatskim kazalištima igrano je 50 predstava religiozne tematike, ali od toga 47 subverzivnih, a samo 7 afirmativnih, i to renesansna prikazanja u sklopu 
ljetnih festivala prezentirana uvijek kao „istraživanje baštine ${ }^{\text {“1 }}$. No, možda je razlog i u regionalnosti, odnosno slabijoj zastupljenosti Slavonije u glavnoj struji hrvatskog kazališta, jer je Marulićeva Judita, upravo kao „istraživanje baštine“, prikazana 1979. na Splitskom ljetu u režiji Marina Carića i dramaturškoj obradi Tonka Maroevića. ${ }^{2}$

\section{Velika obljetnica ili Malo kazalište bez ansambla, ali s velikom vizijom}

Scenska praizvedba Kanižlićeve Svete Rožalije ipak se dogodila 3. srpnja 1999. u Gradskom kazalištu Požega kad se poklopilo nekoliko važnih okolnosti. To je bila godina obilježavanja 300. obljetnice Kanižlićeva rođenja i 300 godina postojanja požeške gimnazije, u kojoj je sam Kanižlić i predavao, a Gradsko kazalište Požega ulazilo je u svoju petu sezonu.

Požega ima dugu kazališnu tradiciju koja kreće upravo od Kanižlićeva vremena i isusovačkog kazališta preko raznih domaćih amaterskih kazališnih i opernih družina, čestih gostovanja stranih putujućih družina, da bi 1948. - 1957. djelovalo profesionalno kazalište. ${ }^{3}$ Godine 1995., nakon gotovo trideset godina, osnovano je Gradsko kazalište Požega, ali bez ansambla, s nekoliko zaposlenih i s minimalnim sredstvima. Ipak su uspijevali odigrati u sezoni 130 predstava, gostovanja raznih hrvatskih kazališta, a svake bi godine, uz amaterski ansambl i profesionalnog redatelja, napravili i barem jednu vlastitu produkciju. Bili su to suvremeni hrvatski tekstovi, od prvog Gle kako lijepo dan počinje Zvonimira Bajsića (režija Ivica Plovanić) preko Ljubavi Georgea Washingtona Mire Gavrana (režija Krešimir Zidarić) do Povratka Srđana Tucića (režija Krešimir Zidarić). Ravnateljica požeškoga kazališta Maja Žebčević Matić željela je od samih početaka kazališta postaviti Kanižlićev ep „,kojim se svi hvale ali ga poznaju samo stručnjaci“, ${ }^{4}$ svjesna kako je to velik i umjetnički i produkcijski pothvat. Velika obljetnica (kao i promjena političkog sustava nakon 1991. te završetak rata 1995. i potreba za definiranjem vlastitog identiteta zemlje i temeljnih vrijednosti) bila je idealna prigoda, pa je Anita Jelić dramatizirala ep. Podrška Ministarstva kulture projektu obilježavanja Kanižlićeve obljetnice dodatno je motivirala stvaratelje. Kako u uvodniku programske knjižice Maja Žebčević Matić kaže: „,smogli smo hrabrosti i ‘drskosti’ požeškoj, hrvatskoj, a i inoj javnosti (...) kroz

1 Sanja Nikčević „Religiozne teme u hrvatskom kazalištu/drami od 1945.-1989. ili kako su rubovi očuvali svjetlo" Kroatologija 1/2019.

2 Ta je izvedba i dramatizacija uvelike pomogla prihvaćanju Judite kao dramskog teksta. Dramatizacija je objavljena: Marko Marulić Judita, Mogućnosti 12/1984., str 939-970. Kasnije je Marin Carić režirao Juditu i u Lutkarskom kazalištu Zadar 1991., a Frano Parać postavio ju je na opernu scenu u režiji Petra Selema (HNK Split, 2002). Ta je dramatizacija i izvedba uvelike pomogla prihvaćanju Judite kao dramskog teksta.

3 Gradsko kazalište Požega, https://www.gkp.hr/o-nama/povijest.html. Pristupljeno 1. 8. 2019.

4 Maja Žebčević Matić „Kako i zašto Kanižlić i Rožalija“ u: Kazališne novine. Gradsko kazalište Požega 1999/2000., 4/1999., str. 6-7. 
univerzalni kazališni jezik približiti vrhunsko djelo hrvatskog književnog baroka i rokokoa, Kanižlićevu Svetu Rožaliju, biser sa dna panonskog mora“. ${ }^{5}$

\section{Susret starog i novog ili važno je dotaknuti dušu}

Budući da su željeli napraviti doista pravu predstavu (a ne prigodničarsku „red Slavonije, red Požege, red Kanižlića, red baroknih kostima“)", okupljena je iznimno talentirana, ali mlada autorska ekipa: Jasmin Novljaković (redatelj), Anita Jelić (adaptacija i dramatizacija), Jasminka Petek Krapljan (izbor glazbe i koreografija), Miljenko Sekulić (scenografija) te Snježana Mostarkić (akcentuacija), uz sudjelovanje petnaest glumaca, članova Srednjoškolske kazališne družine i starijih glumaca: Mirela Hegediš kao sv. Rožalija, Milica Nemeth Panežić kao Majka, Ankica Ivanković kao Samoća, Jasmina Radan kao Sloboda života/Pokora, Branko Lehner kao Ljubav Božja, Draženka Majić kao Kripost, Saba Akllilu Desalegne kao Milost, Ivan Bajt kao Tamburaš, Sanja Mraović kao Razbludnost, Maja Marukić kao Nenavidnost, Marija Topić kao Napast, Viktorija Tijan kao Cerna zgoda, Marija Medić kao Udes, Barbara Živković kao Ljubičak i dvoje djece u raju (Iva Matić, Ana Pezić).

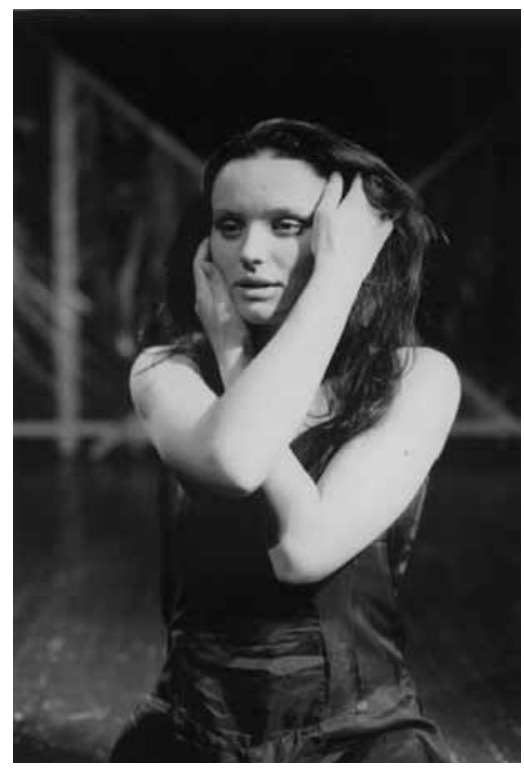

Antun Kanižlić Sveta Rožalija, režija Jasmin Novljaković, Gradsko kazalište Požega, 2019.

Na slici: Rožalija, prva uloga mlade Mirele Hegediš.

Foto: Arhiva kazališta. Objavljeno s dopuštenjem kazališta.

\footnotetext{
5 Maja Žebčević Matić „Poštovani prijatelji gradskog kazališta Požega!“ u: Antun Kanižlić Sveta Rožalija, programska knjižica, Gradsko kazalište Požega, Požega, 1999.

6 Isto.
} 
Dramaturginja Anita Jelić (tada studentica zagrebačke Akademije koja je, nažalost, prerano preminula) svjedoči: „Što više čitam tekst mi je sve draži. To je sjajno napisano. Za čitanje i slušanje. Tu sve hrska i pucka od bezbrojnih onomatopeja, pridjeva i glagola. Full je nakićen taj Kanižlić. ${ }^{\text {"7 }}$ Međutim, to joj ne rješava problem nedostatka dramske radnje i pravocrtnosti glavnog lika. Shvaća da se taj tip starog teksta ne smije modernizirati jer „Ako osuvremenim Rožaliju, motivacije će dobiti suprotan predznak od onih koje je on ispisao. ${ }^{\prime 8}$, pa je ostavila priču u svom vremenu. I dalje je ostao problem prikazivanja glavnog lika jer "suvremeni čovjek nema interesa za crno-bijeli svijet. On preferira kolor. Pa čak kad su u pitanju sile dobra i zla.“, ali uvjerena da: „Negdje mora biti ključ koji će pokazati koliko je

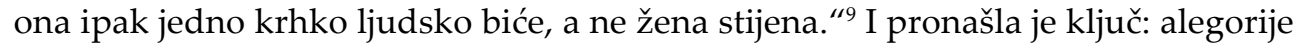
je postavila kao likove u dva kora od kojih su jedni postojani u dobru (Kripost, Milost, Samoća, Ljubav Božja), a drugi na strani zla (Napast, Nenavidnost, Cerna zgoda i Razbludnost). Uz to je uvela i nove likove. Lik Majke koja se Rožaliji javlja u snovima moleći je da se vrati životu i koja je "dovoljno jaka da dovede u sumnju Rožalijinu odluku“. Dodala je i dva "kolebljiva lika“10 koja imaju mogućnost izbora: Tamburaš koji zbog dobre kapljice izabere zlu stranu i Sloboda života koja krive izbore i grijehe okaje suzama kao Pokora da bi nakraju došla u rajsku slavu.

Lik Slobode života direktni je citat srednjovjekovnog djela Svatkovića, moraliteta koji govori o moralnom nauku, odnosno kako ispravno živjeti i spasiti svoju dušu jer bogatom čovjeku usred grijeha dolazi Smrt i dopusti mu jedan dan odgode da očisti dušu (priznanjem grijeha, ispovijedi i pokorom, a uz pomoć dobrih djela i kreposti) koja zato nakraju odlazi u nebo. ${ }^{11}$ Time je Anita Jelić ne samo dodala dimenziju "običnog čovjeka" u svetačkoj priči nego je priču još čvršće povezala s porukom i svjetonazorom originalnog teksta.

Budući da su odlučili igrati na originalnom jeziku (i u stihu), važan je bio posao Snježane Mostarkić, koja je tekst akcentuirala rekonstruiravši izvorni akcent Požege 18. stoljeća. Rožalija je napisana ikavicom, ali po svojim prozodijskim obilježjima pripada staroštokavskome naglasnom sustavu za koji je karakterističan akut, tzv. čakavski akut (koji se još nalazi i u čakavskome i u kajkavskome). Tu

7 Anita Jelić „Pismo ravnateljici“ u: Antun Kanižlić Sveta Rožalija, programska knjižica, Gradsko kazalište Požega, Požega, 1999.

8 Anita Jelić „Bilješke o ‘sv. Rožaliji'“ u: Kazališne novine. Gradsko kazalište Požega 1999/2000., 4/1999., str. 8-9.

9 Anita Jelić „Pismo ravnateljici“ u: Antun Kanižlić Sveta Rožalija, programska knjižica, Gradsko kazalište Požega, Požega, 1999.

10 Isto.

11 Svatković (njem. Jedermann, eng. Everyman) bio je pravi kazališni hit srednjeg vijeka i ostao je na kazališnom repertoaru sve do danas. Hofmannstaelova obrada od 1920. do danas otvara Salzburške večeri, a Tomislav Lipljin uspješno ju je preveo na kajkavski, što je igrano u Varaždinu kao Vsakovič (1996.) 
je pretpostavku, osim u teorijskim zapisima o jeziku, akcentologinja potvrdila na zvučnosti teksta i rime, koja je čujna samo uz taj akcent. ${ }^{12}$

Redatelj Jasmin Novljaković bio je poznat kao član sisačke kazališne grupe Daska, amaterske, ali iznimno važne u tzv. hrvatskom kazališnom alternativnom pokretu osamdesetih godina, kad je najuzbudljivije kazalište (i umjetničkim dosezima i političkom provokacijom) bilo upravo u okviru studentskih grupa ili grupa mladih ljudi. ${ }^{13}$ Nakon desetogodišnjeg boravka u Poljskoj (gdje je završio akademiju te vodio kazališnu grupu) bio se nedavno vratio u Sisak ${ }^{14}$ i rado prihvatio ponudu rada na religioznom tekstu jer: „Iako sam se ranije uglavnom bavio suvremenim tekstovima, odmah sam pomislio da bi ovakva religijska tematika mogla biti dobar izbor. Na studiju mi je ona bila najzanimljivija, pa sam stalno - negdje u glavi - imao želju da bih to jednog dana volio raditi. Kako je ravnatelje kazališta danas teško uvjeriti u atraktivnost srednjovjekovnih crkvenih tema shvatio sam da je Sv. Rožalija prava prilika“. ${ }^{15}$

Rad na predstavi najprije je tekao kao kazališna škola jer je radio $s$ ansamblom kroz dramske vježbe, etide i radionice ne bi li ih upoznao, a i pripremio za glumačke zahtjeve, a onda je iz toga proizašla i podjela. Kad su započeli rad s tekstom, bilo im je „kao da govore japanski“, ali su taj jezik, priča, Rožalija i ostali likovi, potpuno osvojili do te mjere da su za vrijeme rada na predstavi međusobno govorili Kanižlićevim jezikom i osvijestili važna pitanja čovjekova života. Znajući da je problem prikazati u suvremenom kazalištu „borbu crno-bijelih likova a da se ne upadne u banalnu priču", redatelj je pokušao povezati glumce sa sadržajem tako da je postavljao pitanja poput: „Možemo li osjetiti kako je uz nas uvijek Ljubav Božja? Kako bismo danas reagirali da djevojka iz bogatog doma ostavi sve jer joj dosađiva sve što je svitovno i odluči se posvetiti Bogu i poći u pustinjake? Kako danas vidimo pakao čistilište i raj. ${ }^{\text {"16 }}$ Ta je pitanja pretvarao u konkretne zadatke, pa su naprimjer „,dobili zadatak napisati kako pakao, čistilište i raj izgledaju iz nji-

12 Snježana Mostarkić „O akcentu“ u: Antun Kanižlić Sveta Rožalija, programska knjižica, Gradsko kazalište Požega, Požega, 1999.

13 Bile su to uglavnom studentske grupe uz sisačku Dasku, zagrebačku Kugla, Coccolemoco, dubrovački Lero, a kasnije i pulski Inat, zagrebački Ivan Goran Kovačić i karlovački Pinklec. Neki od članova otišli su $\mathrm{u}$ profesionalne kazališne vode, a neki su ostali u svojim grupama do danas (Lero, Pinklec, Inat). Vidi u: Sanja Nikčević „Kazališni amaterizam ili popunjavanje praznina U povodu 52. susreta hrvatskih kazališnih amatera, Stari Grad na Hvaru 16-20. svibnja“ Vijenac, 31. 5. 2012.

14 Danas je Jasmin Novljaković docent na Akademiji za kulturu i umjetnost u Osijeku, gdje predaje glumu i režiju.

15 Karolina Pavić „Stvaranje „sv. Rožalije“ nalikovalo je na put njenog glavnog lika kroz pakao, čistilište i raj", razgovor s Jasminom Novljakovićem u: Kazališne novine. Gradsko kazalište Požega 1999/2000., 4/1999., str. 11.

16 Jasmin Novljaković „Riječ redatelja“ u: Antun Kanižlić Sveta Rožalija, programska knjižica, Gradsko kazalište Požega, Požega, 1999. 
hove perspektive, a potom su morali smisliti i odigrati petominutnu etidu na istu temu. ${ }^{\prime 17}$ Time je dobio od glumaca i razumijevanje priče i poruke, ali i neka odlična scenska rješenja. Radeći na tekstu iz 18. stoljeća, primijenio je rad na predstavi tada zvanih alternativnih kazališta i dobio odličnu glumačku podjelu i maksimum od glumaca (pa se tako Mirela Hegediš pokazala kao „autentična Rožalija“, iako joj je to bila prva uloga).

Srednjovjekovna prikazanja koja su prikazivala tako različita mjesta događanja gradila su za svaku scenu specijalne kućice (tzv. mansije), koje su bile fiksirane ili su putovale na kolima kroz grad, na vrhuncu prikazivanja u 14. i 15. stoljeću trajala su od jednog cijelog dana do 25 dana (francuski grad Valencienne), a cijeli ih je grad financirao. ${ }^{18} \mathrm{U}$ malom požeškom kazalištu to se nije moglo napraviti, pa su tako započeli s praznom scenom, ali ju je ubrzo popunila ne samo glumačka kreativnost nego i kreativnost ostalog dijela autorskog tima i nastala je predstava „alegorične i maštovite režije (npr. detalj kovčega u kojima napasti vuku svoje grijehe), te odlična minimalistička scenografija“. ${ }^{19}$

I onda se dogodilo da je i tekst profunkcionirao na sceni upravo onako kao se dramaturginja nadala: „Tradicionalni tekst (...) Jasmin je realizirao suvremenim rekvizitarijem. On i Miljenko (scenograf) stvorili su svijet velikih ideja i malih ljudi. Dubina i visina požeškog kazališta su im omogućile da kulise postanu velike. Glumci su postali mali, ljudski likovi - okruženi velikim svemirom. Kotačići kulisa ostvarili su moju želju da se svjetovi tijekom scena mijenjaju. Rožalija je postala suvremeno ljudsko biće. Prestala je biti apsolutno ispravna, bezdilemna heroina. Majka je donijela toplinu i moralnu dilemu. Milost, Krispost, Samoća su postale prave Rožalijine prijateljice, prestale su biti papirnate alegorije. (...) Činilo se da je i gledateljima bilo lijepo kao i nama.“ ${ }^{20}$

\footnotetext{
17 Isto.

18 F. S. Perillo, Hrvatska crkvena prikazanja, Mogućnosti, Split, 1978.

19 Karolina Pavić „Zaslužen tretman baroknog bisera u suvremenom obliku“, Kazališne novine. Gradsko kazalište Požega 1999/2000., 5/2000., str. 29-30.

20 Anita Jelić „Bilješke o 'Sv. Rožaliji'“ u: Kazališne novine. Gradsko kazalište Požega 1999/2000., 4/1999., str. 8-9.
} 


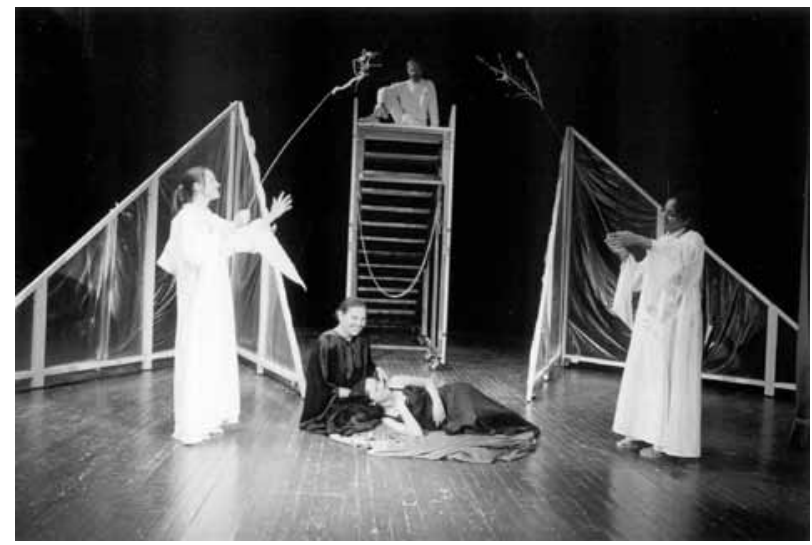

Antun Kanižlić Sveta Rožalija, režija Jasmin Novljaković, Gradsko kazalište Požega, 2019. Na slici: Suvremena scenografija i stilizirani kostimi uz stari jezik i priču o važnosti spasa duše. Foto: Arhiva kazališta. Objavljeno s dopuštenjem kazališta.

\section{Odjek predstave ili na zahtjev gimnazijalaca}

Da su ove riječi istinite, potvrdila je reakcija publike na izvedbama ne samo u Požegi, gdje je odigrano desetak izvedbi (uz uobičajene izvedbe i za sve važne dane grada kao što su Dan grada, Dan učitelja, Sveta Terezija). Predstava je bila uspješna i na gostovanjima po Hrvatskoj. Prvo je bilo u Sisku u povodu svečanog otvorenja nove dvorane sisačkog Centra za kulturu (danas Dom kulture Kristalna kocka vedrine Gradskog kazališta Sisak) 2. listopada 1999., kada je organiziran mali kazališni festival na kojem je, uz požešku Sv. Rožaliju, Hvarsko pučko kazalište odigralo Hektorovićevo Ribanje i ribarsko prigovaranje u režiji Marina Carića, a sisačka grupa Daska izvela Tri lijeva sata. Na okruglom stolu na temu Literarna baština i suvremeno kazalište sudjelovali su Paolo Magelli, Marin Carić, Božena Filipan te autorski dio ekipe Rožalije Jasmin Novljaković, Anita Jelić i Snježana Mostarkić.

Predstava je gostovala 26. ožujka 2000. u Zagrebu u Kazalištu Komedija, u Slatini (18. travnja 2000.), u Zadru (4. kolovoza 2000.), u HNK u Varaždinu (3. studenoga 2000.), u Pazinu (14. ožujka2001.), u HNK u Osijeku (12. travnja 2001.). ${ }^{21}$ U petoj sezoni kazališta (1999./2000.) najizvođenija je predstava bila Petar Pan (igrala se u vrijeme božićnih blagdana) s 21 izvedbom, druga je bila Sveta Rožalija s 12, a treći Alan Ford sa 6 izvedbi. To je malo kazalište i taj je broj izvedbi uspjeh to više što se radi o baroknom epu na sceni za koji su mnogi mislili da je nesceničan ili nezanimljiv suvremenoj publici, a osobito mladima.

${ }_{21}$ Izvor podataka o gostovanjima Kazališne novine. Gradsko kazalište Požega 1999/2000., 5/2000., str. 8-9, $15-16$. 
Pokazalo se da to nije istina, jer sve što su osjetili sudionici predstave - doista je osjetila i publika. Zanimljivo je da su uz dogovorene dvije predstave Rožalije u požeškoj gimnaziji odigrane još dvije na zahtjev gimnazijalaca! ${ }^{22} \mathrm{Na}$ gostovanju u Komediji bila je prepuna dvorana i nakraju se pljesak čuo na stepenicama izvan kazališta Komedija, što potvrđuje Karolina Pavić, koja je tamo dočekala kraj predstave jer nije imala mjesta u prepunoj dvorani za koju su karte rasprodane u dva dana. ${ }^{23}$

Da ta reakcija nije bila samo dobrohotnost zagrebačkih Požežana koji su došli pozdraviti svoje mlado kazalište, dokaz je Dalibor Foretić, jedan od najznačajnijih hrvatskih kritičara. Izvedba u Komediji toliko ga se dojmila da je napisao vrlo pohvalnu kritiku u Vijencu, novinama za kulturu Matice hrvatske, iako nije bilo uobičajeno amaterske predstave prikazivati u novinama tog tipa. Svoj tekst Foretić je zaključio ovako: „Novljaković je, uz pomoć dinamične scenografije Miljenka Sekulića i suradnice za scenski pokret Jasminke Petek Krapljan (koja je izabrala i doličnu glazbu), razigrao predstavu u nizovima živih slika kojima je razbijao monotonost radnje i pokretom oživljavao riječi koje su, uz pomoć akcentologinje Snježane Mostarkić, unatoč arhaičnosti, iz usta uglavnom mladih glumaca djelovale svježe i živo. Novljaković ni u jednom trenutku nije posegnuo za u nas omiljelom persiflažom svetih sličica. Njegovi prizori djelovali su autentično. U njima se scenski živo mogla razabrati Kanižlićeva rokoko kićenost suočena s egzistencijalnim solipsizmom baroka. Možda su zbog toga najdojmljivije djelovali prizori Rožalije sa Samoćom, jedinom drūgom svakoga ljudskog bića, a Kanižlićeva misao koja se najdublje usjekla u sjećanje jest kako je smert života jeka, jer kako svatko sa svojom samoćom živi, tako će i umrijeti. ${ }^{24}$

Očito je i sudionicima i gledateljima ova predstava dotakla dušu, a njihove riječi moguće je provjeriti i danas (barem na vrlo točnoj informativnoj razini) gledanjem videozapisa koji je dostupan u Gradskom kazalištu Požega. Važnost koju je ta predstava imala za kazalište pokazuje i njezina oprema, vrlo profesionalno napravljen program, naslovnica u stilu prvog izdanja tiskane Svete Rožalije, a kasnije i objavljivanje broja Kazališnih novina posvećenih toj predstavi, što sve zahtijeva dodatni organizacijski napor, ali je i danas odličan izvor informacija.

22 Požežani koji su vidjeli predstavu pamte je do danas (a pamte se samo izrazito dobre ili izrazito loše predstave koje smo vidjeli), što je provjereno usmenom anketom i svjedočanstvima za vrijeme znanstveno-stručnog skupa Antun Kanižlić, održanog 15. 11. 2018. u Požegi u organizaciji Hrvatske akademije, odnosno Akademijina Zavoda za znanstveni i umjetnički rad u Požegi.

23 Karolina Pavić „Zaslužen tretman baroknog bisera u suvremenom obliku“, Kazališne novine. Gradsko kazalište Požega 1999/2000., 5/2000., str. 29-30.

24 Dalibor Foretić „Smert života jeka“, Vijenac, 6. 04. 2000. dostupno i na mrežnoj adresi http://www. matica.hr/vijenac/159/smert-zivota-jeka-18395/ 


\section{Izvan kazališta ili kako Kanižlića približiti mladima}

Požeška je predstava, nažalost, ostala usamljena i Sveta Rožalija više nije stala na profesionalne kazališne daske, ali je dospjela na radiovalove. Te obljetničke 1999. godine Nives Madunić za svoju radiodramu Kruva bez motike odabrala je dijelove iz Svete Rožalije. Cijela drama temeljila se na fragmentima iz djelâ slavonske književnosti 18. i 19. stoljeća (tu su i humoristična pjesma A. Ivanošića Sličnorični natpis groba Zvekanova, Godovno J. S. Relkovića, Slavonska Judita, Satir M. A. Relkovića) „stvorivši tako fresku onodobnoga pučkog života u Slavoniji“ ${ }^{“ 25}$. Radiodramu je režirala Vedrana Vrhovnik, sudjelovali su glumci Darko Milas, Zvonko Torjanac, Pero Juričić, Helena Buljan, Inge Apelt, Dubravka Carić, Vesna Tominac, Goran Grgić, Suzana Nikolić i Emil Glad, a nagrađena na međunarodnom festivalu Prix Marulić 1999.

Iduće godine (3. svibnja 2000.) za Hrvatski radio snimljena je radiodrama Svete Rožalije u režiji Stephanie Jamnicky, a glumili su: Natalija Đorđević (kao sv. Rožalija) i Inge Appelt (glavne uloge); Ana Karić i Edita Majić, Marija Kohn, Alma Prica Tomislav Rališ, Hrvoje Handl (srednje uloge) te Dora Polić, Vanda Vujanić-Šušnjar i Davor Svedružić.

Požega je povezana s Kanižlićem te njegovim likom i djelom jer temeljna obrazovna institucija (osnovna škola) nosi njegovo ime, a u njoj se često i obilježavaju Kanižlićeve obljetnice. Tako je nakon Svete Rožalije i sam Kanižlić stao na scenu. Za to je osobito zaslužna učiteljica OŠ Antuna Kanižlića i dramska pedagoginja Slavica Jelić, koja kontinuirano te s puno ljubavi i predanosti odgaja mlade Požežane da zavole kazalište. Dvadeset i dvije godine vodila je Malu školu kazališta pri Gradskom kazalištu Požega (kroz koju je u 40 predstava prošlo preko 400 predškolaca i učeni$\mathrm{ka}$ ), a do mirovine 2019. postavljala je različite predstave i organizirala programe s učenicima u školi. ${ }^{26}$

Slavica Jelić organizirala je 2015. u OŠ Antuna Kanižlića projekt o Kanižliću radi boljeg upoznavanja tog pisca: „U anketama koje smo proveli primijetili smo da učenici ne znaju puno o Antunu Kanižliću. Odlučili smo se na akciju i pokrenuli radionice koje je radio nastavnik povijesti Goran Đurđević, a na današnjoj radionici tema nam je njegova biografija i djelo, posebice Sveta Rožalija koju želimo pročitati s učenicima osmih razreda. ${ }^{\prime 27} \mathrm{Na}$ radionicama su sudionici doista i čitali jer se tamo na zanimljiv i dinamičan način usvaja znanje, a onda ih je posjetio i sam Kanižlić u

25 Leksikon radija i televizije, HRT Zagreb, 2017. (Interent i tiskano izdanje) te povodom reprize 8. 4. 2014. na http://radio.hrt.hr/ep/kruva-bez-motike/203819/. Pristupljeno 1. 8. 2019.

26 M. B. „Najdraža učiteljica Slavica Jelić nakon 42 godine rada odlazi u mirovinu, donosimo vam par redaka o njenom životu“, 034portal.hr, 6. 4. 2019. https://www.034portal.hr/najdraza-uciteljica-slavica-jelic-nakon-42-godine-rada-odlazi-u-mirovinu--donosimo-vam-par-redaka-o-njenom-zivotu-136 Pristupljeno 1.10.2019.

27 Sanja Pok „Kanižlićevci o Kanižliću“ Slavonski.hr, 16. 11. 2015. http://slavonski.hr/kanizlicevci-o-kanizlicu-govorio-je-o-vaznosti-skole-i-znanja-i-onda-i-danas-to-je-aktualno/ Pristupljeno, 1. 8. 2019. 
isusovačkoj reverendi i kapici (igrao ga je Marko Šarčević, učenik osmog razreda). Posjeti Kanižlića učenicima na satovima razrednika nastavili su se i idućih godina.

U OŠ Antuna Kanižlića 2017. godine učenici su za Dan škole odigrali predstavu Vrijeme Antuna Kanižlića. ${ }^{28}$ Tekst su napisale vjeroučiteljica Besika Vrbanić (s. Slavka) te učiteljice Valentina Mirković i Slavica Jelić. Uz plesnu koreografiju Ilijane Lončar i Marine Mihelčić, u predstavi su nastupali učenici, a Kanižlića je glumio Mijo Radić. ${ }^{9}$ Obilježavanje Kanižlićeva života u toj se školi nastavlja, pa su krajem 2019. pokrenuti Dani Antuna Kanižlića te je objavljena knjiga o njegovu životu Tko je Antun Kanižlić? autorica Besike Vrbanić (s. Slavka) i Valentine Mirković uz ilustracije Dragana Matičevića.

\section{Snaga baroknog epa traje ili možda je sad vrijeme...}

Unatoč čestim sumnjama stručnjaka u sceničnost religioznih tekstova i baroknih poema za suvremeno kazalište i suvremenu publiku, požeška Sveta Rožalija najbolji je dokaz da barokni ep može govoriti i danas - ne samo govoriti nego i izazvati ono što je Aristotel smatrao svrhom kazališta, katarzu koja pročišćava osjećaje ${ }^{30}$ i zbog toga nas ojačava i uzdiže. Sveta Rožalija to je uspjela i na sceni i izvan nje. U Kazališnim novinama koje su izašle nekoliko mjeseci nakon predstave Anita Jelić svjedoči da je Kanižlić ne samo zaživio na sceni nego: „I na kraju, dogodilo se još nešto. Kanižliću je u kazalištu postalo pretijesno. Tijekom ljetne pauze članovi ansambla pošli su na zasluženi odmor - a razglednice koje su stizale osim toplih pozdrava sadržavale su i parafraze Kanižlićevih stihova. Nedjeljni izleti postali su prigodna mjesta za citiranje Svete Rožalije. Slavonski hrastovi postali su Kanižlićevi recipijenti. Rožalija je stvarno oživjela." ${ }^{31}$

Upravo zato što su je svi tako intenzivno doživjeli, Požežani su bili uvjereni da će ta predstava djelovati na cijelo hrvatsko kazalište. Najviše su očekivali od zagrebačkog gostovanja („gdje su se okupila brojni uglednici političkog kulturnog i gospodarskog života, eminentna imena domaćeg glumišta, kazališni redatelji, kritičari, kulturni djelatnici“"32) ali, iako je sama predstava bila uspješna po broju izvedbi i go-

28 Mladen Mirković „OŠ Antuna Kanižlića Požega. Odigrana predstava "Vrijeme Antuna Kanižlića", Požega,hr, 23. 3. 2018. https://www.034portal.hr/clanak.php? $z=1502 \& i d=0 \& c=1 \& r=1 \&$ width=1093\&H eight=615 Pristupljeno 1.08.2019.

29 M. V. „OŠ Antuna Kanižlića Školska godina u znaku 240 godina od smrti književnika čije ime nosi“, Požeški dnevnik, 30. 8. 2017. http://pozeskidnevnik.hr/kultura/4629-os-antuna-kanizlica-skolska-godina-u-znaku-240-godina-od-smrti-knjizevnika-cije-ime-nosi.html Pristupljeno 1. 8. 2019.

30 Aristotel, „O pjesničkom umijeću“ u: Povijest književnih teorija, ur. Miroslav Beker, SNL, Zagreb, 1979, str. 29-60.

31 Anita Jelić „Bilješke o ‘Sv. Rožaliji?“ u: Kazališne novine. Gradsko kazalište Požega 1999/2000., 4/1999., str. 8-9.

32 Karolina Pavić „Zaslužen tretman baroknog bisera u suvremenom obliku“, Kazališne novine. Gradsko kazalište Požega 1999/2000., 5/2000., str. 29-30. 
stovanja, ipak se hrvatsko kazalište glavne struje nije okrenulo i tom tipu predstava nego je nastavilo slijediti trendove. Odnos suvremenog europskog kanona prema baštini vrlo je sličan odnosu prema religioznim temama jer sve afirmacije smatra nevrijednima, a samo kritiku društva iz sekularističke pozicije smatra vrijednom umjetnosti. ${ }^{33}$ Taj je kanon na vlasti od kraja Drugog svjetskog rata, ali ga je ratno vrijeme u Hrvatskoj poništilo, pa se kazalište okrenulo temeljnim vrijednostima i predstavama koje nose katarzu u sebi. Nakon rata svi smo se ponadali da će umjetnost odgovoriti na potrebu za definiranjem vlastitog identiteta zemlje i temeljnih vrijednosti, ali se ona vratila trendovima. Odatle onaj osjećaj ravnateljice da je za postavljanje Svete Rožalije potrebna "hrabrost i drskost" - ne zbog financijskih i organizacijskih skučenosti kazališta nego iz osjećaja da se, afirmirajući hrvatsku baštinu, ali kroz afirmaciju vrijednosti kršćanskog svjetonazora (a ne kao početaka pismenosti), ide protiv trendova koji vladaju u umjetnosti. Zbog tih trendova odlična Sveta Rožalija hrabrih i zanesenih ljudi iz Požege nije imala nastavljače u profesionalnom hrvatskom kazalištu.

Možda je došlo vrijeme da se objavi uspješna dramatizacija Anite Jelić i da Kanižlić zakorači i na druge hrvatske kazališne scene. Sudeći prema dojmu koji i sudionici i gledatelji predstave nose, ona ima ono što suvremenom kazalištu nedostaje: priču koja govori o najvažnijim stvarima u životu čovjeka i daje odgovore na vrlo ozbiljna pitanja o smislu života kroz likove koji donose ispravne odluke. Prvo desetljeće 21. stoljeća pokazalo je da su u krizi i vladajući sekularni svjetonazor, koji je u potpunosti izbacio transcendentno, a i umjetnost glavne struje koja ga odražava. Unatoč svim novcima, medijima i pozicijama moći, sekularistička kritika na sceni završila je u plakatnim predstavama koje izbacuju političke uvrede sa scene, žive na skandalima, ali gube publiku. ${ }^{34}$ To dokazuje da je židovski psihijatar Viktor Frankl u pravu. On je nakon iskustva preživljavanja nacističkog logora (kao dio bečkog kruga psihijatrije paralelno s Sigmundom Freudom, koji je potencirao važnost seksualnosti, i Alfredom Adlerom, koji je potencirao važnost volje za moć) razvio logoterapiju ili liječenje smislom tvrdeći da bez smisla koji uključuje transcendenciju čovjek ne može opstati ne samo u logoru nego ni u suvremenom „životu obilja“. ${ }^{35}$ Kanižlić je to davno znao nudeći nam u Rožaliji evo slike svita za onoga tko ga vidit hoće. ${ }^{36}$

33 Sanja Nikčević "Vjerske teme u hrvatskom kazalištu: preživljavanje na rubovima?" u: Vjerska tematika $u$ hrvatskom medijskom prostoru, Zbornik radova znanstvenog simpozija i projekata na Hrvatskom katoličkom sveučilištu u Zagrebu (zbornik), ur. Jerko Valković, Hrvatsko katoličko sveučilište, Zagreb, 2019., str. 29-46.

34 Isto

35 Viktor Frankl Nečujan vapaj za smislom, Naprijed, Zagreb, 1987.

36 Replika Ljubavi u razgovoru s Rožalijom (Dio Treći, I., stih 2192). Vidi u: Antun Kanižlić Sveta Rožalija, Privlačica, Vinkovci, 1994., str. 75. Dostupno i na: http://dzs.ffzg.unizg.hr/html/Kani.htm. Pristupljeno 1.10.2019. 
Uvjerena sam da je suvremenom čovjeku nužno pogledati upravo tu sliku jer nas podsjeća na ono najvažnije u životu (spas duše). Uvjerena sam i da će suvremeno kazalište biti doista relevantno samo ako ima snage, unatoč sekularističkim trendovima, vratiti priču o transcendentnom na kazališne scene.

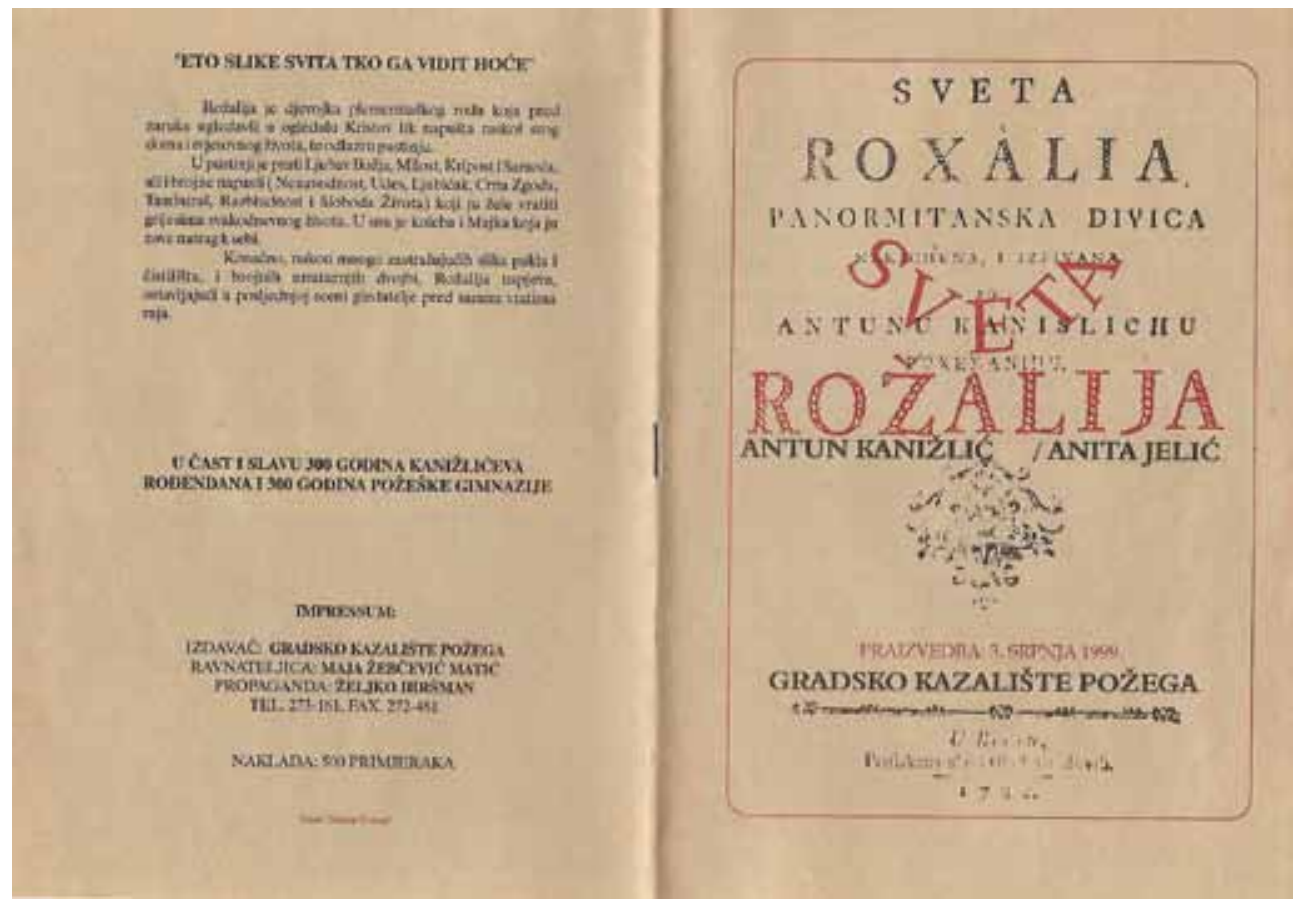

Antun Kanižlić Sveta Rožalija, režija Jasmin Novljaković, Gradsko kazalište Požega, 2019. Na slici: Naslovnica programske knjižice predstave.

Foto: Arhiva kazališta. Objavljeno s dopuštenjem kazališta. 


\section{Sveta Rožalija in Theatre}

Summary

Sveta Rožalija was first performed in 1999 at the Požega City Theatre, on the occasion of marking the $300^{\text {th }}$ birth anniversary of the author. Talented young professionals (director: Jasmin Novljaković; adaptation and dramatization: Anita Jelić; choice of music and choreography: Jasminka Petek Krapljan; stage design: Miljenko Sekulić; accentuation: Snježana Mostarkić), cooperating with fifteen actors from Požega, members of the secondary-school theatrical troupe, and actors of the older generation, created an exceptionally successful performance combining Baroque text, language and accent of the $18^{\text {th }}$ century with modern visual approach. Starting with the question what the message of the topics tackled by the long poem today is, they demonstrated how interesting this Baroque long poem actually is for a modern spectator, since it speaks about the thing that is missing from the modern stage - the sense of living, while portraying the potentially right and wrong answers to the problems of life through characters. Unfortunately, this was the only theatrical performance of this work (apart from a radio drama). However, in 2017, students of the Antun Kanižlić Primary School presented Kanižlić as a character in the play Vrijeme Antuna Kanižlića (The Time of Antun Kanižlić).

Keywords: Antun Kanižlić; Croatian theatre; Croatian drama; Požega City Theatre; Anita Jelić; Jasmin Novljaković.

Prof. dr. sc. Sanja Nikčević

Akademija za umjetnost i kulturu u Osijeku

Trg kralja Petra Svačića 1/F, 31000 Osijek

sanja.nikcevic@uaos.hr 
